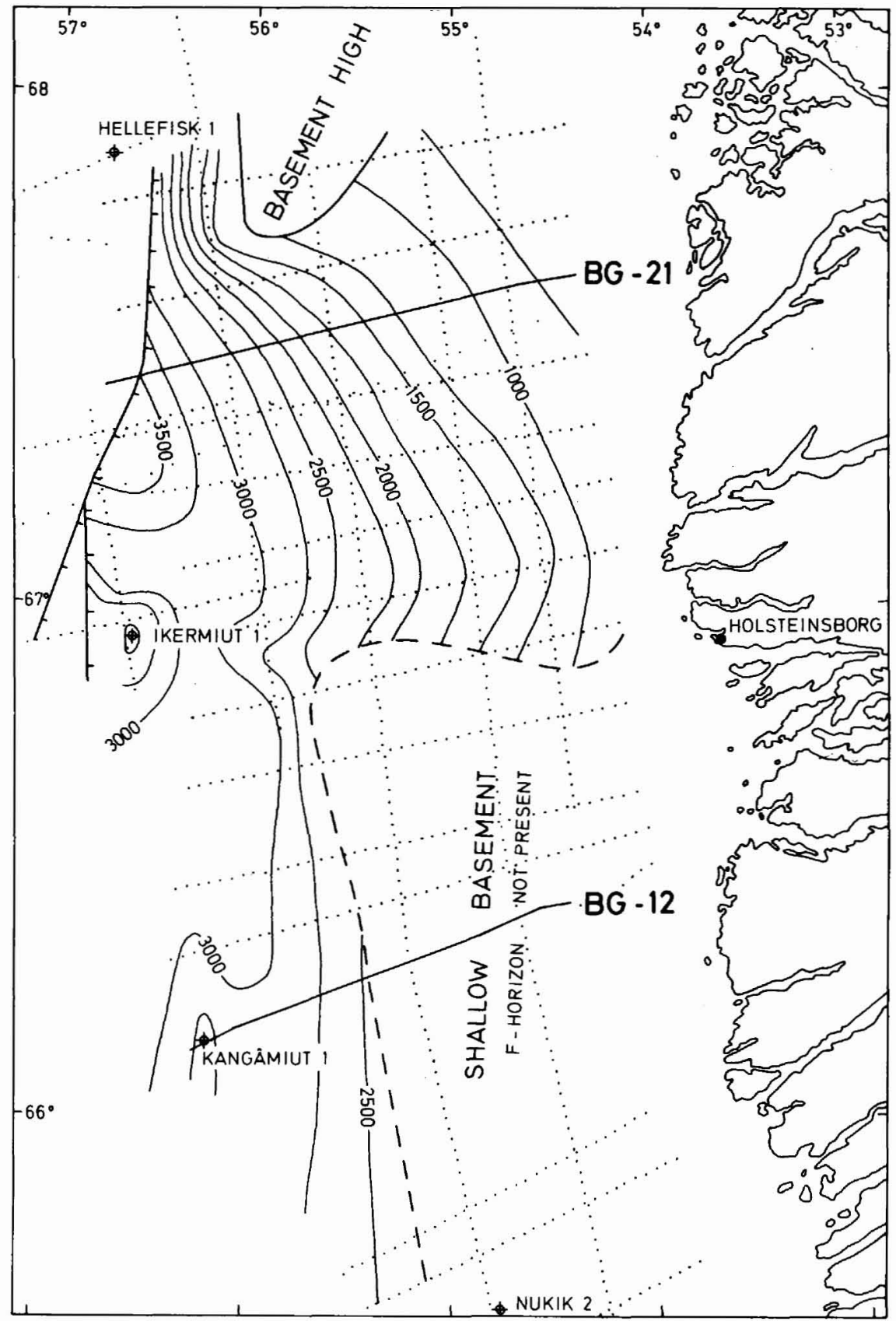

Fig. 18. Generalised map of the F-horizon. Contours in milliseconds. Dotted lines indicate seismic control. 


\title{
Seismic mapping of Lower Tertiary sediments offshore West Greenland between $66^{\circ}$ and $68^{\circ} \mathrm{N}$
}

\author{
Jørgen B. Risum
}

During 1977 and 1978 the first data obtained from commercial petroleum exploration of the West Greenland shelf were released (Henderson, 1978). The release consisted of geophysical data, mainly in the form of reflection seismic sections, and of a summary of information from the Kangâmiut 1 well (Geological Survey of Greenland, 1978). This was drilled during 1976 to a total depth of 3874 metres, and allows the geophysical interpretations to be tied into a stratigraphical framework.

\section{Regional setting of the F-horizon}

During 1978, the F-horizon, as one of the most important reflectors in the area, was remapped by the Survey (fig. 18). This marker is the deepest seismic event that can be mapped regionally and is a fair to good reflector. In Kangâmiut 1 the F-horizon is not marked by any distinct lithological change, but is situated within a uniform, shale dominated sequence dated Paleocene (Geological Survey of Greenland, 1978).

In the northeastern part and in the eastern parts of the area between $67^{\circ}$ and $68^{\circ} \mathrm{N}$, the F-horizon is very shallow and is apparently unconformably overlain by recent sediments (fig. 18).

Towards the west the F-horizon is cut by a fault which has a north-northeasterly strike, running from approximately $67^{\circ} 45^{\prime} \mathrm{N}, 56^{\circ} 30^{\prime} \mathrm{W}$ to $67^{\circ} 00^{\prime} \mathrm{N}, 57^{\circ} 00^{\prime} \mathrm{W}$. Lack of seismic coverage prevents the tracing of the fault further south. At the intersection with line BG-21 (fig. 19) the fault has a throw of more than 4 kilometres.
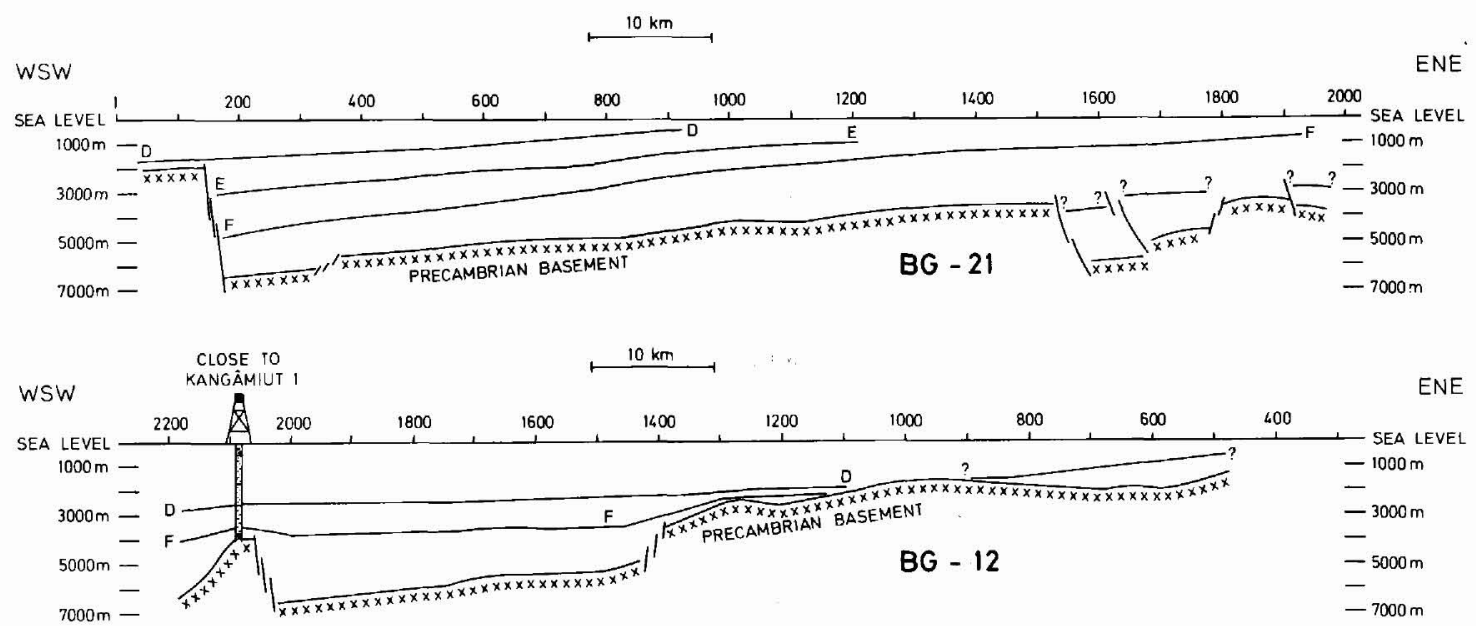

Fig. 19. Interpretation of profiles BG-12 and BG-21. Figures on horizontal axis are Common Depth Point numbers. 
Towards the north the horizon either onlaps the basement or is truncated by younger sediments.

South of $67^{\circ} 00^{\prime} \mathrm{N}$ the horizon is seen to continue on the outer shelf beyond the shelf edge towards the west, and with the existing coverage an immediate termination of the horizon towards the south appears to be unlikely. This could indicate that the basin was open in this direction during the Paleocene.

South of $67^{\circ} 00^{\prime} \mathrm{N}$ an extensive area of shallow basement (fig. 18) strongly affects the distribution of the F-horizon on the inner part of the shelf. The F-horizon is interpreted as onlapping the basement in this area.

\section{Depth and dip of the F-horizon}

In Kangâmiut 1 the F-marker corresponds to a depth of 3300 metres. At the downthrown side of the fault shown on line BG-21 (fig. 19) the depth is calculated to be 4800 metres. The two profiles shown in fig. 19, BG-12 and BG-21, indicate depth in metres to the F-horizon, Stacking velocities are the basis for these depth estimates, which are thought to be accurate within 10 per cent.

The F-horizon shows a regional dip of approximately 3 degrees towards the west in the northern part of the basin between $67^{\circ}$ and $68^{\circ} \mathrm{N}$. In the area south of $67^{\circ} \mathrm{N}$ this dip is not nearly as pronounced.

\section{Structure}

In the area around $67^{\circ} 00^{\prime} \mathrm{N}, 56^{\circ} 30^{\prime} \mathrm{W}$ the horizon shows intense folding, apparently caused by shale diapirism. This interpretation is based on the fact that the shale encountered in the lower part of Kangâmiut 1 was strongly undercompacted (Geological Survey of Greenland, 1978). It is assumed that this general area was the depocentre during the Paleocene. Differential loading may have caused the mobilisation of the shales (Bishop, 1978), with the active faulting to the west as a possible additional factor.

Beyond the major fault and folding related to shale diapirism, the F-horizon is undisturbed and the only major structural features are related to basement highs like the Kangâmiut 1 structure as seen on BG-12 (fig. 19).

\section{The D-horizon}

The D-horizon is another regional seismic event which has been mapped by the Survey. This horizon is found to be present in the western part of the whole area between $66^{\circ} \mathrm{N}$ and $68^{\circ} \mathrm{N}$.

The position of the D-horizon within the sedimentary section is indicated on the two profiles BG-12 and BG-21 (fig. 19). In Kangâmiut 1 this seismic marker is found within a section of Late Eocene age. Thus, assuming that the D-horizon represents an isochron the very pronounced faulting in the northwestern part of the area must predate the Late Eocene.This faulting is tentatively related to the Paleocene volcanism and its associated tectonic activity which is seen in the central West Greenland onshore basin (Clarke et al., 
1976). As about 4 kilometres of sediments are missing on the upthrown block to the west of the fault, this block must have been exposed for a considerable time.

\title{
References
}

Bishop, R. S. 1978: Mechanism for emplacement of piercement diapirs. Bull. Am. Ass. Petrol. Geol. 62, 1561-1583.

Clarke, D. B. \& Pedersen, A. K. 1976: Tertiary volcanic province of West Greenland. In Escher, A. \& Watt, W. S. (edit.) Geology of Greenland, 364-385. Copenhagen: Geol. Surv. Greenland.

Geological Survey of Greenland 1978: Well data summary sheets. August 1978. Kangâmiut 1.

Henderson, G. 1978: Developments in petroleum exploration offshore West Greenland during 1977. Rapp. Grønlands geol. Unders. 90, 32-36.

\section{Project WESTMAR - A shallow marine geophysical survey on the West Greenland continental shelf between latitudes $64^{\circ}$ and $70^{\circ} \mathrm{N}$}

\author{
Colin P. Brett and Edward F. K. Zarudzki
}

Project WESTMAR is designed to provide detailed knowledge of the geological and geotechnical properties of the sea-floor and shallow sub-surface with particular reference to the exploration and development of any hydrocarbon resources in the area, as part of an energy-related research programme sponsored by the Danish Ministry for Commerce. An extensive shallow marine geophysical survey was undertaken during June and July 1978 on the West Greenland continental shelf in the region $64^{\circ}-70^{\circ} \mathrm{N}$ (fig. 20). Approximately 8000 line $\mathrm{km}$ of sparker seismic, magnetic and bathymetric data were acquired together with 4000 line $\mathrm{km}$ of side-scan soner/sub-bottom profiler data. Accurate and continuous position fixing was achieved with an integrated satnav/doppler sonar navigation system. A preliminary interpretation of the data is presented in a separate report (Brett \& Zarudzki, 1979).

\section{Reference}

Brett, C.P. \& Zarudzki, E. F. K. 1979: Project Westmar - A shallow marine geophysical survey on the West Greenland continental shelf. Rapp. Grønlands geol. Unders. 87, 29 pp. 